Article

\title{
Christian Ethics and Ecologies of Violence
}

\author{
Luke Beck Kreider ${ }^{\mathbb{D}}$
}

Religious Studies, University of Virginia, Charlottesville, VA 22903, USA; lbk3vx@virginia.edu

Received: 13 August 2019; Accepted: 30 August 2019; Published: 31 August 2019

\begin{abstract}
This essay introduces "ecologies of violence" as a problem for Christian ethics. Understanding the links between violence and the natural environment will be critical to the pursuit of justice, peace, and sustainability in the twenty-first century. Yet these links often evade political action and escape moral attention because they do not fit comfortably within any of the fields requisite to address them. In most cases, the available resources for confronting these issues-"environmental issues" and "peace and conflict issues" - exist in separate toolkits, and no single discourse has developed resources to address their progressively merging spheres of concern. The essay outlines four types of ecological violence, examines recent work in Christian ethics relevant to them, and then argues for a dialogical method of ethics to confront them. Doing Christian ethics at the intersections of violence and environmental issues will require careful attention to environmental ethics as well as to the ethics of violence. More than that, it will require judicious efforts to navigate between them within case-based and place-based ethical analyses. Ecologies of violence invite Christian ethics to develop possibilities of ethical discernment and reparative action that do justice to the deep entanglement of ecological and sociopolitical systems.
\end{abstract}

Keywords: Christian ethics; environment; ecology; war; violence; environmental ethics; ethics of war and peace; ecological theology; political theology

\section{Introduction}

The interconnections between violence and the natural environment are attracting attention, and for good reason. When the United States Department of Defense urged Congress to consider climate change an "urgent and growing threat to our national security" in 2015, they echoed a widening corpus of scholarly literature suggesting that human-caused environmental changes compound the conditions for violent conflict. ${ }^{1}$ At the same time, researchers have drawn attention to the enormous ecological significance of contemporary warfare, as modern weaponry and military-industrial production exert both immediate and long-term impacts on non-human species and ecological systems. ${ }^{2}$ Understanding the links between violence and the environment will be critical to the pursuit of justice, peace, and sustainability in the twenty-first century. How Christian ethics engage ecologies of violence will help determine how the field conceives its purposes and executes its methods, and will play a major role in shaping what the Christian tradition comes to mean in an era of entangled social and environmental systems.

Ecologies of violence often evade political action and escape moral attention because they do not fit comfortably within any of the fields requisite to address them. The causes and consequences of violence exceed the purview of ecological ethics, environmental policy, or resource management;

(United States Department of Defense 2015; Homer-Dixon 1999; Diehl and Gleditsch 2001; Burke et al. 2015).

(Stockholm International Peace Research Institute 1975; Westing 1990; Grunawalt et al. 1996; Austin and Bruch 2000; Hupy 2008). 
frameworks responsive to political violence do not account for the conveyance of harm and hostility through ecological systems. Especially within North Atlantic Christianities, the available resources for confronting these issues-"environmental issues" and "peace and conflict issues"—exist in two separate toolkits. The field of Christian ethics in particular has neglected to develop discourses or practices addressing their progressively merging spheres of concern.

This essay introduces ecologies of violence as a problem for Christian ethics. It distinguishes four broad types of connection between violence and natural environment, all prominent and morally urgent in diverse places across the globe today. It offers an explanation for why these issues have rarely been treated as matters of Christian concern despite clearly falling within the scope of the tradition's ethical interests, before turning to a few recent works in the field that take initial steps toward Christian ethics attuned to the links between climate change and violence. The essay builds from critical engagements with these pioneering works toward a constructive argument for how to do Christian ethics for ecologies of violence. Doing Christian ethics at the intersections of violence and environmental change will require careful attention to environmental ethics as well as to the ethics of violence. More than that, it will require judicious efforts to navigate between them, to develop possibilities of ethical discernment and reparative action that do justice to the deep entanglements of ecological and sociopolitical systems.

With rare exceptions, the gap in moral discourses and practices connecting ecology and violence spans the entire range of Christian denominations and theological schools in the North Atlantic. Focused efforts to critique and expand Christian capacities to engage violent ecologies will no doubt take diverse paths, drawing from distinctive theological, cultural, and sociological sources. But the conceptual and functional rift at the intersection of sociopolitical and ecological systems is a remarkable point of confluence among the tradition's many streams. That rift is this essay's point of departure.

\section{Ecologies of Violence}

Violence can be propelled by, committed against, and conveyed through ecological systems. This has always been the case, but a number of factors converged in the late twentieth century to make the environmental dimensions of violence more visible and more pressing. ${ }^{3}$ Several media-saturated military campaigns-notably the Vietnam War and the Persian Gulf War-perpetrated catastrophic environmental damages, raising alarms about the ecological consequences of armed conflict. In the United States in the late 1970s, grassroots groups organized in opposition to public and corporate land use practices that disproportionately exposed working class minority communities to harmful toxins, ultimately spawning a national movement and a moral paradigm ("environmental justice") focused on how discriminatory patterns of land management diminished the lives of people of color by contaminating their environments and thereby poisoning their bodies; they thus drew attention to how ecological systems may become channels of racialized violence. ${ }^{4}$ Most prominently, ever-increasing concerns about climate change have forced attention to the intimate relations of human society, political economy and earth, as planetary forces (shaped at least in part by human forces) threaten to generate or intensify social and political turbulence at multiple scales.

In short, there has been a general trend toward seeing the natural environment entangled with various forms of violence. But seeing this as a trend requires gathering together distinct and disparate strands of contemporary discourse on conflict, violence, and ecological stress. For the most part, these issues emerged independently and have been treated under separate cover. A rare effort to engage several in tandem is made in Nicole Detraz's book Environmental Security and Gender, which distinguishes but also interlinks three now-prominent fields at the intersections of security and environment: (1) environmental conflict, which considers armed conflict over natural resources,

$\begin{array}{ll}3 & \text { See (Stone 2000). } \\ 4 & \text { See (Bullard 1990) }\end{array}$ 
(2) environmental security, which engages environmental degradation as a problem for human health and well-being, and (3) ecological security, which treats environmental degradation as a problem in itself, assessing strategies to protect non-human creatures and ecological systems from the negative effects of human behavior. ${ }^{5}$ In addition to providing one of the most lucid and comprehensive overviews available, Detraz shows how each of these intersections is further entangled with gender, and so develops a compelling argument for a feminist environmental security discourse. ${ }^{6}$ In the fields of Christian theology and ethics, the idea that despoliation of the environment is intimately linked to the oppression of women has been well-established by eco-feminists and ecowomanists since the mid-1970s, ${ }^{7}$ and the gendered dimensions of warfare were famously raised by Jean Bethke Elshtain and more recently by Susan Brooks Thistlethwaite. ${ }^{8}$ Conceptual parallels and historical alliances between white supremacist violence and colonialist patterns of environmental exploitation have been highlighted by James Cone, George Tinker, and Dianne Glave, among others, ${ }^{9}$ while Martin Luther King, Jr. is only the most celebrated name to have preached about the interlocked dynamics of racism and militarism in the United States. ${ }^{10}$ But rarely have Christian thinkers followed Detraz in closing the triangle, engaging identity-based oppressions where environmental issues and political violence converge. Still fewer consider these intersections together in light of the religious practices and frameworks through which they are often experienced, constructed, reinforced or resisted.

To treat links between violence and environment as a problem for Christian ethics means to ask questions about Christian moral life amidst this tangled web of relations. It means struggling to orient ecclesial responses to complex systems of suffering that traverse conceptual boundaries and bind together spheres of life that Christians (of the North Atlantic) have traditionally considered separate. The term ecologies of violence attempts to capture this complexity. The field of ecology engendered a paradigm shift in the life sciences in the early twentieth century, as the new discipline endeavored to understand organisms in terms of their relationships with others and with their environments, examining how the cycling of energy and nutrients through the biotic and abiotic elements of a community shape the patterns, quality, abundance, distribution and diversity of life in a place. Natural scientists do not typically use the term "ecology" as a plural noun-the dynamic systems they study are not "ecologies" but rather "ecosystems" - but humanists and social scientists speak of "ecologies" to describe the systemic interrelations that shape the conditions and the experiences of human communities, especially in light of the environmental channels-transformations of land, extractions and distributions of water and minerals, energy regimes, emissions of particulates into the air, alterations to global atmosphere, and so on-through which humans interact with each other and with other creatures. In this modified usage, ecologies entail the many ways human individuals and communities continuously shape and are shaped by their social and natural habitats. The term ecologies of violence directs attention to how ecological systems and environmental conditions affect, integrate, and convey relationships of harm, domination, and diminishment among human beings and between human communities and the rest of nature.

Understood in this light, the connections between violence and the environment are not narrow concerns or niche interests reserved for specialists. They encompass the intersectional dynamics of violence in exceptionally wide scope. For Christian ethics, attention to ecologies of violence invites thinkers to reconnect political theology to creation and theological anthropology to place; it attunes social and environmental ethics to systemic and intersectional problems, raising questions about how to conceive and orient Christian life where the orders of creation bear the wounds of human sin;

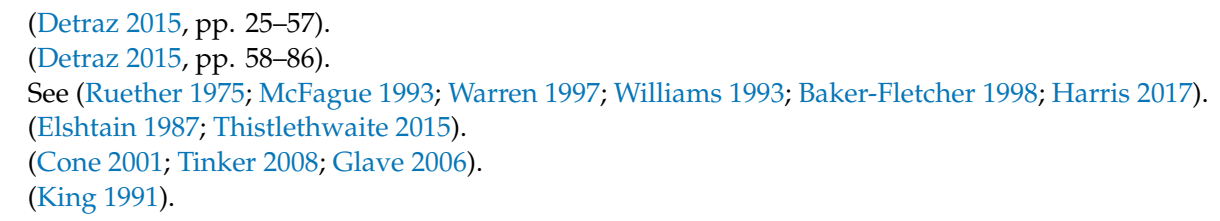


it keeps the field responsive to lived reality, and elicits virtues of dialogue now crucial to the discipline and basic to moral engagement in pluralist environments.

\subsection{Ecologies of Violence: Four Types}

One possible reason that the ecology of violence has not been treated as a subject for Christian ethics is that the links between violence and environment are so many and so varied that they confound integrated analysis. An important first step is to map the relations at a legible scale. Although a fair bit of reductionism is involved in any such effort, Christian ethics could begin to engage ecologies of violence with attention to four basic types.

\subsubsection{The Ecological Drivers of Conflict and Peace}

The first type tracks the various ways that environmental changes, ecological forces, and natural resources factor into the onset, objectives, and resolutions of violent conflict. This encompasses what Detraz and others refer to as "environmental conflict," meaning conflict over scarce natural resources. Knowing that heightened climatic variability is likely to create severe stresses-and in many places critical scarcities-for the basic necessities of human life (e.g., water and food), many now predict a marked rise in "resource wars." The logic is straightforward: if environmental change leads to resource scarcity, and if people groups compete and often fight over scarce resources, then environmental change is likely to occasion inter-group competition and probably violent conflict.

But competition over resources like water and arable land is just one way ecological forces bear on conflict. Another is that planetary changes-e.g., sea-level rise and ocean warming-and related extreme weather events contribute to human migration, which in turn seem to affect the entrenchment of national identities and to deepen ethno-religious resentments, uprooting vulnerable populations and often driving them into other ecologically marginal and/or politically hostile lands. Another is that changing land- and seascapes factor into the transformation and renegotiation of regional and global political economy, threatening to unsettle already unstable civil and international relations.

The prevalence, probability and relative causal force of all these (and more) ecology-violence connections are debated; what is no longer questionable is that they merit urgent attention. The oft-cited potential for global climate change to displace peoples, catalyze resource conflicts, and aggravate social hostilities ${ }^{11}$ is only the most sensational aspect of a growing body of scholarship tracing the relationships between environmental conditions and the prevalence of violence. Political scientists attempt to measure the impact of environmental factors on the outbreak of armed conflict, and debate the causal mechanisms at play. ${ }^{12}$ Scholars in the adjacent fields of international relations and strategic peacebuilding discuss the significance of resource management and sustainability for violence prevention and conflict resolution. ${ }^{13}$ "Environmental peacemaking" is now an active field of research and practice, ${ }^{14}$ and climate change is arguably "the hottest issue in security studies."15

The issues have attracted so much attention, in fact, that many now worry about the "securitization" of ecological discourse and environmental politics. ${ }^{16}$ Hans Günther Brauch argues that national security and defense now constitute the main reasons offered in public for combating climate change, at least in the Global North. He tracks a marked increase in global climate policy discussions framing Anthropocene challenges in terms of existential threats and national security concerns. Interpreting climate change as a national security risk (rather than an environmental problem or a justice issue) has been instrumental in mobilizing the climate change mitigation and adaptation regimes of North

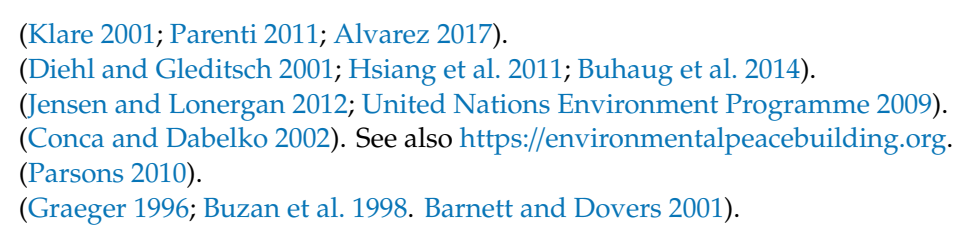


Atlantic countries, he claims. ${ }^{17}$ It is therefore no surprise to notice that the Department of Defense and the armed forces are arguably the sectors of the U.S. federal government that have engaged most seriously with climate change. Timothy Doyle and Sanjay Chaturvedi point to the recent "securitization and often militarization" of state responses to human migration as a key reason to be cautious about embedding climate politics within a security framework. ${ }^{18}$ Daniel Deudney and Mark Zeitoun worry that security frameworks inject parochial assumptions, antagonistic norms, and militarized institutions into environmental politics, replacing important values like justice, participation, and human rights. ${ }^{19}$

Securitized environmental discourses also tend to view the significance of climate change and ecological degradation in an entirely anthropocentric frame. They risk foreclosing moral considerations or political strategies that include the interests of non-human creatures or the earth itself, or that honor the intimacies of human communities with their ecological relations. Relatedly, they often reinforce what Pope Francis calls the "technocratic paradigm," which treats creation as an inert object awaiting rational management by human experts and elites. The field's dominant disciplinary frameworks sheer the issues of key religious and moral valences. This poses both a problem and an opportunity for Christian analyses of environmental conflict. These same challenges will attend Christian reflection on ecologies of violence across all four types.

\subsubsection{The Environmental Consequences of War}

The second type concerns the impacts of warfare and military industrial production on natural environment. Armed combat endangers human and non-human inhabitants in and around warzones as it destroys or intoxicates the ecosystems in which they live. Used as a weapon, threatened as a target, and imperiled as collateral of military aims, the environment has never been immune to the violence of war. War's environmental impacts are especially pernicious in the advent of modern weaponry, the production and deployment of which releases chemical and biological particulates that cycle through water, air, and soil, and often into human and non-human bodies. For this reason, environmental scientists now attempt to track the impacts of modern warfare on war-zone ecologies, biodiversity and the human environment, ${ }^{20}$ and military ethicists and international lawyers seek frameworks to evaluate and regulate the environmental effects of war-making. ${ }^{21}$

Much of this scientific, legal, and moral attention to wartime environmental destruction was catalyzed by the international scrutiny that followed the Vietnam War, during which the United States used herbicides and high-explosive munitions, systematically cleared land and bombed dams, and tinkered with the possibilities of strategic climate modification, endeavoring to turn the weather into a weapon of war. ${ }^{22}$ The Persian Gulf War prompted another wave of consternation, when Iraqi troops set oil wells ablaze and caused the world's worst-ever oil spill, while coalition forces used cluster bombs and depleted uranium shells to destroy Iraq's water and sanitation works. The fallout from these conflicts illustrated how the environment broadens and magnifies war's destructive power, lengthening its temporal horizon, widening its spatial reach, carrying its sting across the borders of species and into the guts of the earth. ${ }^{23}$

The environmental impacts of war are distinct for the ways they spread the hazards of battle through ecological ripple effects-violence relayed through ecosystemic relations. ${ }^{24}$ The effects of a discrete, carefully calibrated combat action may fan out through food chains and energy cycles, or leave its toxic legacy blowing in the wind or flowing through rivers, aquifers and pipes. When the

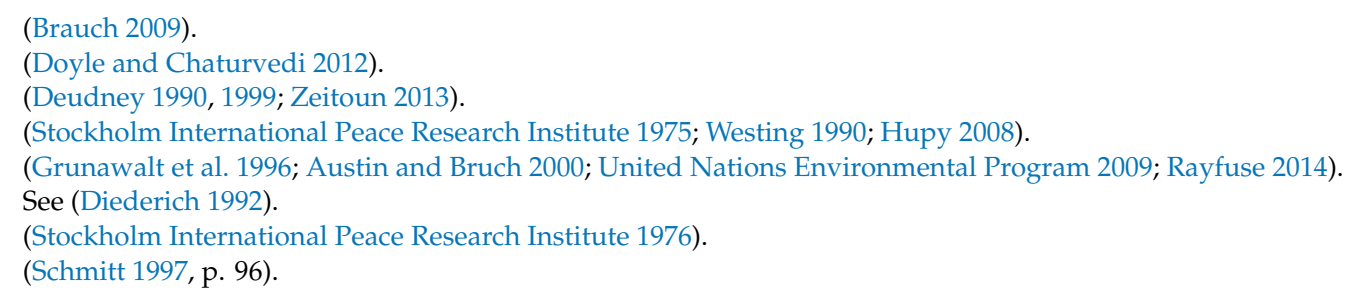


environment is a victim of war, it also becomes a medium of political violence toward creatures great and small. When wars degrade the natural conditions necessary for life and well-being, they perpetrate arbitrary harms on civilians and other noncombatants. In the traditional language of military ethics, environmental destruction in war is indiscriminate violence-it extends the brutality of combat into the dwellings of innocents, human and non-human alike.

In fact, some ethicists have begun to consider how the Just War Tradition (JWT) could be adapted to interpret and address war's environmental impacts. Gregory Reichberg and Henrik Syse attempt "to show how the rich soil from which the just war tradition has grown includes elements relevant to the contemporary debate on the environmental consequences of war." 25 They draw on the theology of Thomas Aquinas to suggest how the tradition's philosophical foundations could also ground the moral value of nature, and so bring environment under the protections of the JWT's in bello principles. Mark Woods argues that careful considerations of potential environmental impacts should be part of just war deliberations ad bellum. ${ }^{26}$ More recently, Matthew Shadle and Laurie Johnston have engaged Catholic Social Teaching on war in light of environmental degradation. ${ }^{27}$ These efforts indicate the potential for Christian ethicists to deploy classical concepts in new ways to confront the challenge of ecological violence.

Yet the standard frameworks for morally assessing violence as well as the established ways of doing environmental ethics are vexed by the environmental consequences of war. Christian ethics of war and peace have not developed conceptual resources to grasp what is at stake-ethically or theologically-in the destruction of nature, and they have limited practical tools to orient lived responses to ecological violence. For environmental ethics, the complex couplings of ecological and human systems always create complications, but war is typically understood as a unique moral sphere, "a zone of radical coercion, in which justice is always under a cloud." 28 There are few precedents for interpreting and applying ecological values under the fog of war.

\subsubsection{Land Conflict}

Conflicts over land-including disputes over how to value, use or inhabit particular lands, and clashes over who land belongs to (or who belongs to the land) - entail a third kind of connection between violence and environment. Land conflict in the sense meant here is related to but distinct from what is typically called "environmental" or "resource" conflict. Environmental/resource conflicts are typically defined by competition over scarce resources, and are characterized by the ways ecological forces-especially environmental stresses and changes-stimulate those struggles. But conflicts over land use are not necessarily motivated by resource competition or driven by climatic or other environmental changes. Although they may sometimes feature disputes about the economic value of land, they are ultimately about the moral value and cultural meaning of contested places. Land conflicts share features of religious conflicts, in that they are often clashes of identities organized around group-defining lifeways and emplaced worldviews.

In After Nature, Jedediah Purdy argues convincingly that the embattled history of American land settlement and management is in part a story of rival "environmental imaginations." Environmental imagination refers to a people's way of thinking about and acting in relation to their natural environments. It is a group's distinct "way of seeing" the natural world, their "pattern of supposing how things must be." Carried by myths, narratives, lifeways, land policies, and so on, environmental imagination encompasses the significance of a group's ecological thought and practice to their

\footnotetext{
(Reichberg and Syse 2000, p. 451).

(Woods 2007).

(Shadle 2011; Johnston 2015). Shadle also addresses environmental degradation as a "cause" of war.

(Walzer 2004, p. x).
} 
constructions of identity and meaning. "It is an implicit, everyday metaphysics, the bold speculations buried in our ordinary lives," writes Purdy. ${ }^{29}$

From the beginning-unmistakably from the time of the first indigenous settlement, and overwhelmingly from the time of European colonization - the human presence in North America has been ecologically revolutionary, wiping out species, changing soils and plant mixes, and reshaping the surface of the earth. At least since Europeans conquered the continent, that ecological revolution has been deeply involved in contests over imagination, over the meaning of the world and the right way to live in it. ${ }^{30}$

After Nature shows how the bloody struggles over the possession and character of American soil transformed landscapes across the continent according to opposing conceptions of nature-ecological worldviews embodied in communities, enshrined in law, and religious in depth. America's originary history of ethno-religious land conflicts helped mold the nation's cultural and political identities as it fashioned a country speckled with sacred places disputed by many, protected and preserved for some, pillaged, desecrated and displaced for others.

Some of America's most celebrated sacred places—e.g., Yellowstone National Park—remain theaters of conflict between rival cultures and their competing land policies. In The Battle for Yellowstone: Morality and the Sacred Roots of Environmental Conflict, Justin Farrell argues that conflicts over the Greater Yellowstone Ecosystem remain embittered and intractable because dominant frameworks for understanding environmental policy disputes fail to grasp the "deeper cultural mechanisms" at play. The long-simmering hostilities at America's favorite secular sanctuary are part of "an underlying struggle over deeply held 'faith' commitments, feelings, and desires that define what people find sacred, good, and meaningful in life at a most basic level." ${ }^{\prime 31}$

Purdy's history of U.S. environmental policy and culture, and Farrell's sociological analysis of conflict at Yellowstone both reflect a pattern visible in diverse political and geographical contexts across the world: Land use disputes are more than inter-group conflicts over competing interests; they are cultural, ideological, and religious clashes. This is true even where parties are avowedly "secular" actors. At stake are the intertwined histories of nature and culture, of environment and identity-the pairs bound together by the embodied environmental imaginations hosted within a place, by their everyday ecological politics and their engagements with the sacred.

There is no field of study or body of research dedicated to land conflict so defined. Here is an opportunity for scholars of religion to lend their field knowledge and disciplinary tools to the critical study of ecologies of violence. For Christian ethicists to contribute to this work, however, the field will have to develop strategies for historically-informed and place-based inquiry into conflicted ecological faiths. Christian communities have lived such faiths in many times and places, with monumental implications for the formation of the tradition, for the moral lives of its practitioners, for their neighbors, and for the lands they passed through and in which they dwell.

\subsubsection{Structural Violence Conveyed through Environmental Systems}

Many climate justice advocates argue that the injustices associated with climate change reflect and even mediate deep-seated patterns of violence. Climate change is a symptom and a vehicle of structural violence, they argue. ${ }^{32}$ Johan Galtung, a pioneer of peace and conflict studies, famously defined structural violence as "violence [that] is built into the structure and shows up as unequal power and consequently as unequal life chances." 33 For Cynthia Moe-Lobeda, structural violence names

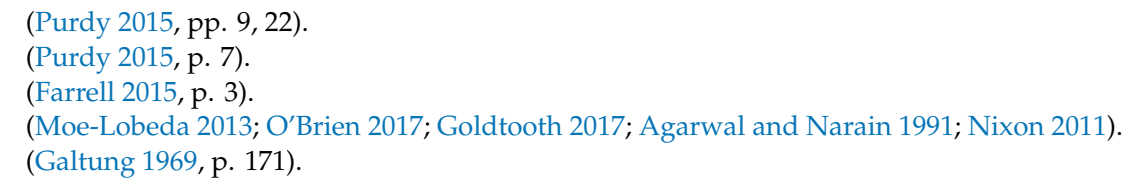


systemic, interlocking processes which operate through human agency but function independently of any individual humans to "degrade, dehumanize, damage, and kill people by limiting or preventing their access to the necessities for life or for its flourishing." It is "harm that certain groups of people experience as a result of unequal distribution of power and privilege," and it includes the "complicity or silent acquiescence of those who fail to take responsibility for it and challenge it." ${ }^{\prime 34}$

Calling climate change structural violence focuses moral attention on the conditions of persistent inequality that follow climate change from its origins in the developed world's disproportionate uses of environmental resources and atmospheric space, through its political negotiation in global arenas marked by radical imbalances of power, to its projected consequences, which will be most severe for the poor and other vulnerable groups. A close look at climate change attunes us to the strange possibility that violence may flow through ecological and atmospheric systems. This sort of violence, despite its structural scope, environmental medium, and accidental infliction, is no less real: it still strikes, still harms, still coerces and deprives.

The idea of ecologically-mediated violence need not seem strange, suggests Willis Jenkins, because ecology itself is political. ${ }^{35}$ Nothing reveals that more clearly than persistently unequal distributions of environmental hazards. In the U.S., for example, toxic exposures, ecological degradations, and severe resource deficiencies are distributed along lines of class and especially race. The color of your skin is the best sociological predictor of how many unwanted chemicals have penetrated your body through your water, air, and soil. ${ }^{36}$ Globally, the environments of the poor and the indigenous are degraded and destroyed through long-term dynamics of "resource capture" and "unequal ecological exchange." ${ }^{\prime 37}$ Those historical relations are also implicated in the global poor's special vulnerabilities to climate-shaped threats like sea-level rise, severe drought and flooding. In short, the wounds wrought by climate change and other forms of environmental change highlight how harms flow gradually across time and space, finding vulnerable victims through the politically forged channels of ecological systems. Rob Nixon calls this "slow violence"- ecologically-transmitted violence that occurs "out of sight, a violence of delayed destruction ... an attritional violence that is typically not viewed as violence at all." Slow violence is "incremental and accretive," with "calamitous repercussions playing out across a range of temporal scales." 38

The concept of slow violence makes visible processes and relations that degrade and destroy through hidden channels. It thereby aims to subject environmental injustice to the strict moral censure reserved for acts of violence, and elicits moral and political responses that take seriously the suffering of its victims and the malice, negligence, or complicity of its perpetrators. Similarly, when advocates of climate justice place the causes and effects of climate change under the category of violence, they present a more dire account of the problem, and arguably appeal to a more demanding and holistic set of responsibilities. The category also guards against seemingly effective, efficient solutions that would nevertheless reinforce underlying patterns of inequality and exploitation. ${ }^{39}$

Typically, the field of climate justice is concerned with how to allocate fairly the costs of mitigating and adapting to climate change. ${ }^{40}$ It argues over what factors should matter most when assessing those allocations, and how to measure and weigh harms and risks that are inequitably distributed across the globe's already uneven geographies of vulnerability, wealth, and power. Movements for environmental justice likewise take systemic inequalities and structural oppressions into account when meting out justice, but typically remain within a proceduralist and distributivist paradigm. Acknowledging climate change, racist ecologies, and resource capture as forms of ecologically-mediated structural

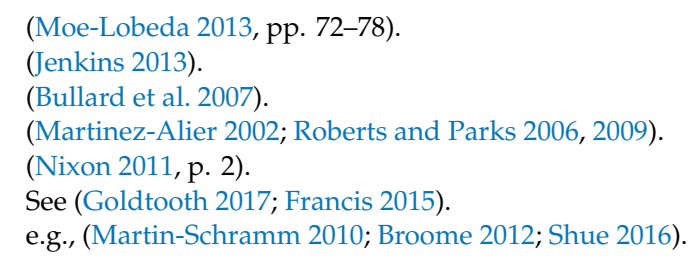


violence implies that justice requires more than fair cost allocation and burden sharing, more than due process and equitable distributions of benefits and burdens. At minimum, interpreting such relations within the moral and political jurisdiction of violence seems to call forth practices of rebuke, accountability, and repair.

A full picture of the requirements of justice will depend on which moral frameworks and political precedents for responding to violence are brought to bear on cases of ecological violence. Here is another opportunity for Christian ethics to take up the challenge of addressing crucial contemporary connections between violence and the environment. But the challenge here is considerable. While structural violence seems an apt description of many of the evils of climate change, determining just responses to climate violence is difficult because responsibility and culpability is hard to track across all the confounding spatial and temporal scales through which climate change contributes to human suffering. Another important question is whether the paradigm of structural violence can make moral sense of humanity's relations to the non-human world, or whether the typically anthropocentric category of violence obscures the pain and silences the cries of "Sister, Mother earth." 11

It is worth noting that the typology of ecological violence above is not the only possible way to map this material, nor is it necessarily comprehensive. As the fourth type makes clear, the question of how violence relates to the environment is partly an interpretive question, and always a discursive strategy, an attempt to frame pressing moral issues in terms of their social-ecological intersections. As all four types indicate, interpreting these issues at their intersections is a strategy with both promise and peril, risking, among other things, anthropocentering and securitizing environmental discourses, overextending and thus weakening the moral scope of violence, and overwhelming ethical competencies. Yet ethical reflection at these junctions holds considerable promise, not only for helping Christian moral life to catch up to Anthropocene challenges, but also for restoring Christian faith to an integral understanding of human personhood in the context of creation, and so to help Christian communities remain responsive to God's self-disclosive activity in the world.

Other possible maps might chart anthropogenic environmental degradation as a form of direct violence against non-human creatures or against the earth. Perhaps high-intensity agriculture does violence to the soil, or deforestation commits violence against forest creatures, and this should be treated as a distinct form of ecological violence. While plausible, this interpretation is not explored here. Not including it signals an impulse to set limits on the interpretive frame of violence for Christian environmental thought. As a concept describing acts and relationships, "violence" illumines some qualities of relations and obscures others. Applying it in so direct a way to human treatments of nature may crowd out ecocentric ways of understanding our ecological connections, even as it attempts to de-anthropocentralize the concept of violence. A strong argument could be made for adding a type to encompass the use of armed force to protect the environment ${ }^{42}$ and the militarization of ecological conservation. ${ }^{43}$ If these dynamics continue to grow in prominence, they may come to warrant separate treatment, but for now can be treated as distinctive forms of land conflict. Still other possible maps would create special places for the ecological dimensions of race-, class- or gender-based violence. But these intersections permeate the entire range of violent ecologies, so they are not treated as distinct types here. Instead they should be understood as pervasive features of the sociology of ecological violence. All four types should be investigated with attention to these penetrating and constitutive dynamics.

What the four types have in common are the embedded inter-relations of human societies within ecological systems, and thus the ways environments bear the forces of human enmity and strife.

41 (Francis 2015). Willis Jenkins raised questions like these in (Jenkins 2017).

42 See (Eckersley 2007). Eckersley proposes "ecological intervention" as an ecocentric corollary to humanitarian intervention, probing the ethical implications of the "responsibility to protect" in light of imminent threats to nature.

43 (Duffy 2014). 
Despite their differences, they all demand integrated moral analyses that cross environmental, political, and religious thresholds. Can Christian ethics do such work?

\section{Perennial Gaps, Unprecedented Problems, and Some Recent Christian Ethics}

Long-standing efforts to call attention to the ecology of violence-notably on land use conflicts and climate change, and mostly from thinkers from the Global South, indigenous communities, and liberationist traditions-struggle to influence the dominant Christian ethical discourses in the North Atlantic, where a violently won sense of environmental security combines with a deeply rooted conceptual poverty, making claims of ecological violence from the margins appear morally unimportant, if not theologically unintelligible. One way of accounting for the incapacity of North Atlantic Christian ethics to grasp the nature and significance of ecologies of violence can be found in Willie J. Jennings's extraordinary book The Christian Imagination, in which he argues that modern Euro-American Christianity was born in the severance of peoplehood from land. Recall Jedediah Purdy's notion of imagination as a "way of seeing, a pattern of supposing how things must be" and an "implicit, everyday metaphysic." Jennings argues that the dominant North Atlantic Christian imagination has seen human beings in terms of race instead of place, portable bodies enfleshed in color rather than integral peoples in kinship to earth. With the colonial construction of race as a category of human identity-forged in processes of frontier settlement through land seizure that displaced millions, and patterns of land and property ownership that objectified places into resources and people into slaves-Christianity "rendered unintelligible and unpersuasive any narratives of the collective self that bound identity to geography, to earth, to water, to trees." 44

If these colonial histories seem remote-they are not-the underlying religious imaginations still readily appear. The Native American theologian George "Tink" Tinker writes of native peoples' continual frustrations in the struggle to have their collective identities "recognized and respected as distinct political entities based on specific land territories." Instead, well-meaning liberals bundle native concerns under the placeless logics of race- or class-based politics. ${ }^{45}$ "The earth has been taken from us and given back to us changed," laments Jennings. "Thus our lives, even if one day freed from racial calculations, suffer right now from a less helpful freedom, freedom from the ground, the dirt, landscapes, and animals, from life collaborative with the rhythms of God's other creatures." 46 Perhaps this is one reason Christian ethics has struggled to grasp ecologies of violence as problems for Christian life: the Christian imagination, even in its progressive forms, will not conceive social or political life as enmeshed in ecological relations. ${ }^{47}$ Ethicists have inherited practical and epistemic incapacities to do politics with nature, symptoms of a still deeper split between collective identity and place.

Further evidence for such a divorce is reflected in the near total separation between environmental and political theology, between the tradition's ecological ethics and its moral reflections on violence, conflict and peace. Christian environmental thought has developed quite a large library since the 1970s, but has almost never treated the problem of inter-human violence as part of its domain. Christian ethics hosts rich streams of reflection and practice on the ethics of violence, justice, and peacemaking, but these seldom encompass relations with non-human nature or the slow flow of harms through ecosystemic processes and atmospheric space.

The tradition's moral and practical frameworks for confronting environmental issues and political violence rarely overlap. Environmental ethics and the ethics of violence and peace remain discrete domains, even as their spheres of concern entwine in increasingly visible ways. Both want to promote flourishing in a world where it is no longer possible to think about justice and peace apart from ecological systems and environmental conditions, but both face questions foreign to their fields.

\footnotetext{
(Jennings 2010, p. 59).

(Tinker 2008, p. 23).

(Tinker 2008, p. 290).

Cf. (Jenkins 2018).
} 
How should environmental ethicists respond to resource conflicts spawned by both environmental change and social divisions? How do peacebuilders assess and redress the ways environments mediate structural violence? For now, each field works with tools adapted for its own parochial environs, and a lack of dialogue threatens to leave both disciplines lagging behind the demands of their subject matter.

Yet growing concerns about climate change are just beginning to spark efforts to do ethics across some of these boundaries and to tackle the intersectional issues of climate violence. Perhaps that is because some in the field are beginning to see that the tradition's typical moral patterns are "imperiled by unprecedented problems," as Willis Jenkins has put it. The complexities and uncertainties of climate change occasion ethical innovation "when reform projects take their incompetence as a demand to create new possibilities from their inherited traditions." ${ }^{\prime 4}$ Four Christian ethicists have recently tackled connections of violence and climate change, offering clues to how the field could proceed.

Michael Northcott diagnoses a problem similar to the one discussed above, but instead of implicating the Christian imagination Northcott blames the "modern West" and its secular analysts with their Enlightenment roots. "The foundational Enlightenment separation between nature and culture, and hence between natural history and the history of the earth, is the core conundrum of climate change," he writes in A Political Theology of Climate Change. ${ }^{49}$ Northcott argues that Western political scientists miss the connections between climate and conflict because they tend to "decontextualise politics from geography, and culture from nature." To make sense of the fractious politics of a warming world, contemporary conflict "needs to be presented in ways that make the connections between climate and culture." ${ }^{50}$ He claims that the "Enlightenment distinction between nature and culture, facts and values," has left moderns with an objectified vision of nature, rendering the moral and political significance of climate change conceptually opaque. ${ }^{51}$ For Northcott, the modern West's continual resistance to the reality of climate change is rooted in an ingrained Kantian folly-namely, the decoupling of scientific and practical reason, and the segregation of rational human activity from the sacramental vitality of the natural world. ${ }^{52}$ Climate science takes on theological significance as it "reveals that the cosmos is again, as it was for the Ancients, a source of value and revelation, a living being with which humans are in a living relations, involving exchange and negotiation. ${ }^{153}$ Christians learn the same in church (or they should), where eco-structural sins are repented and worshippers "rediscover the primordial unity of all persons and creatures." 54

Northcott takes pains to argue that Christian leaders and organizations were among the very first to address climate change as a genuine moral and political challenge. ${ }^{55}$ But while he claims that Christian political theology has the necessary resources to confront environmental conflict, he offers no explanation for why the field has overwhelmingly failed to do so. Even Northcott's own work, which acknowledges climate conflict as a problem worthy of theological reflection, does not attend to the particular relations between environmental change and human violence from a Christian perspective. Still, if the conceptual alienations of nature and culture, place and identity, underlie the practical incompetence of Christian ethics before ecologies of violence, then Northcott's project represents one plausible way forward, focused on theological repair of public imagination. On the other hand, when his self-assured, even triumphalist account of Christianity attempts to evade complicity in the entangled legacies of colonialism, white supremacy, and the anti-ecological imaginations he agrees are at the root of climate change, Northcott abdicates responsibility for his own tribe's history of

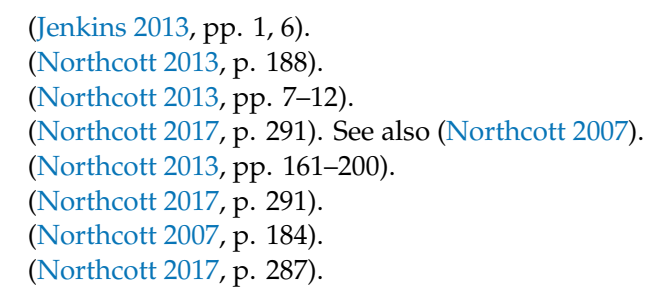


violence, and so replicates the very kinds of politics that insulate from scrutiny the structural violence of climate change.

Mark Douglas's important new book Christian Pacifism for an Environmental Age takes a much more critical approach to Christian history and theology. He argues that Christian pacifism formed around a mythologized narrative of immaculate origins, and that early pacifist pretensions to ecclesial purity were implicated in the formation of an imperial church that pursued political power by recourse to coercion and exclusion. ${ }^{56}$ The early church's pacifism was furthermore bound up with anti-Semitism, developing supersessionist hermeneutics and "schismatic tendencies" that have endured in pacifist theological politics, tendencies too often "rooted in judgments against and condemnation of other politically weak, marginalized, and/or oppressed communities." 57

But Douglas's criticisms are part of an effort to reconstruct the Christian ethics of nonviolence in light of natural history and especially "climate-shaped conflict." "We are entering a new social imaginary shaped by environmental concerns," he writes. Living in the Anthropocene-Douglas calls it "the Environmental Age"-humans now understand the world and their place within it "through environmental lenses." Christian pacifists need to reform their ideas and practices for this emerging epoch, when conflict and violence are increasingly "environmentally shaped." 58

Reconstructing Christian pacifism begins by "understanding our place in time." ${ }^{29}$ By this he means primarily three things. First, it means understanding something about the particular moral challenges of the Environmental Age, including environmental conflict. Second, it means better understanding the history of Christian pacifism. And finally, it means interpreting both of the above within a theological understanding of God's action in history.

The vast majority of the book is devoted to the second task, which for Douglas is an effort to use historical method to complicate and destabilize the mythic narratives pacifists have rallied around. "In demythologizing pacifism, I hope to temporalize-and thereby humanize-it," he explains ${ }^{60}$ It is by humanizing pacifist history that he hopes to help today's pacifists acclimatize to the Environmental Age. When pacifists realize that the early church was never uniformly pacifist and that the tradition's founding theologians were anti-Semites complicit in the theological formation of empire, perhaps they will stop closing ranks, stop turning their noses up at the rest of the world, and instead learn to accept responsibility for their contributions to global environmental problems and to "pursue common cause with disparate others in dealing with climate-shaped conflict." 61

One of the most illuminating features of the book is that Douglas attempts to narrate the rolls played by weather, climate, and geological events in the formation of pacifist tradition. As climatic changes shaped conflicts in late medieval Europe, "they also shaped the movements of pacifist thought." ${ }^{62}$ Climatic changes have shaped the Christian ethics of violence and nonviolence- - this is a momentous insight, especially for an environmental age, when ecological changes are predicted to be unsettling at unprecedented scales. ${ }^{63}$ By arguing that traditions of Christian moral thought developed within communities' theo-ethical responses to environment, Douglas takes a step toward relocating religious history in its ecological setting, and so opens space for Christian ethics to grasp ecological violence within the orbit of lived faith.

Where Northcott rehabilitates a premodern doctrine of Creation to re-stitch culture and politics to earth, Douglas turns to recent work in environmental history to show how natural forces usher traditions through time. Both are efforts to link Christian political imagination to ecology in order

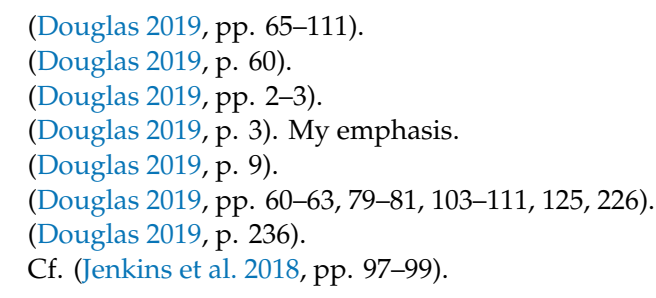


to prepare Environmental Age communities to address problems fundamentally linked to planetary change. But the most forceful conclusion drawn from Christian Pacifism for an Environmental Age is not about the natural world but about the nature of history. "When we ignore the impact of climate on history, we unnecessarily and unduly truncate the range of forces that shape history." ${ }^{\prime 64}$ The theological significance of climate change seems primarily to reinforce certain best practices for religious historians: It is one reason among many to adopt a more subtle hermeneutic of tradition, so that those who look to history for moral inheritances can supply more complex and ambiguous readings of the past. Complex and ambiguous religious histories are, in turn, useful in the Environmental Age-more useful than essentialized, mythologized histories-because the moral postures they support are unburdened of perfectionism, purity, and divisiveness, and more open to irony, bricolage, and collaboration. Irony, bricolage, and collaboration will be virtues in the environmental age because climate change reveals moral conditions of universal complicity, ambiguity, and interconnectedness, and because meaningful solutions require working together. These are important points, if a bit simplistic, and the overall achievements of the book are a tremendous contribution to the history and historiography of Christian pacifism and an insightful effort to renew the tradition for a new era.

But what that renewed tradition can offer in terms of orienting practical pacifist moral engagement with climate-shaped conflict remains under-developed in the book. What can pacifist ethics do for climate violence? In the Afterward, Douglas envisions another book, one "that picks up where this one leaves off. How will Christian pacifism respond to violence caused by the movements of climate refugees, the competitions over increasingly scarce basic resources like grains and water, the political destabilizations of new pandemics, and other politico-ecological crises?" He says he hopes to write this book soon. ${ }^{65}$

Writing that book well will likely require some engagement with environmental ethics and Christian environmental thought. For a project aiming to renew traditions of Christian morality in light of environmental concern, Douglas's book has surprisingly little to say about the moral or theological significance of natural environment. How, where, and why does the non-human world have moral and/or theological value? Of what import is ecology to Christian faith? How does creation make claims on Christian lives? These questions matter for how Christian ethics engage ecologies of violence, and any practical approach to issues like climate-shaped conflict will answer them implicitly if not reflectively. Douglas's account seems to frame environment primarily as a set of external conditions creating social pressures. Mainly, it is the weather, which over time or through extreme events can be "disordering" to established ways of thinking and living. Climate change is a theological problem just because all serious shifts- "whether technological, political, or economic" - to the objective conditions of social life prompt people to ask questions, some of them theological, typically about God's presence in history. ${ }^{66}$

"In Euro-American (and European) philosophical and theological history it is more common to see intellectual reflections on the meaning of time; it is far less common to see intellectual reflections on space," observes Tinker. Most Native American worldviews and lifeways centered on space, he says. This has been reflected in their deep attachments to particular places, where peoplehood is conceived in responsible kinship to earth, to land and its diverse inhabitants. The genocidal displacement of native peoples in North America was the triumph of time-the conquest of land and people within providential history, interpreted as progress, sustained still in liberal narratives of development and in the banishment of earth from political imagination. ${ }^{67}$ "The most destructive value that the European invaders imposed is the quantification and objectification of the natural world," writes Tom Goldtooth (Executive Director of the Indigenous Environmental Network) in a paper about the moral dangers of

\footnotetext{
(Douglas 2019, p. 239).

(Douglas 2019, p. 248).

(Douglas 2019, p. 235).

67 (Tinker 1997, pp. 96-99).
} 
many seemingly reasonable responses to climate change. ${ }^{68}$ Where history replaced creation as the primary domain of God's presence, environment was desacralized, and promptly desecrated.

These are of course fairly sweeping narratives, and perhaps they are just the kinds of monochrome histories Douglas works so strenuously to unsettle in his book. But stories about the erasure of place and the expulsion of earth from modern North Atlantic theological imagination proliferate in environmental theological literature. They are important in the context of arguments about how to respond to climate violence because they show what is at stake ethically and theologically in how climate change is interpreted as a problem and, relatedly, how human communities decide to address it. For Goldtooth, responses to climate problems that replicate the objectification of earth also tend to "entrench and magnify social inequalities," and worse, they "promote violation of the sacred, plain and simple." ${ }^{69}$ Pope Francis argued much the same thing in Laudato Si. ${ }^{70}$ Understanding why indigenous peoples, religious leaders from the Global South, many theologians of color in North America, and many others see things this way requires, in part, an effort to understand the social and theological significances of place, natural environment, and ecological relationships. An effort to see ecology in its social and theological depth is requisite to the capacity to engage issues like climate displacement, land conflict, and "resource" scarcity in full moral scope. By focusing on the Anthropocene's recalibration of time, Douglas misses an opportunity to consider how climate change and other ecological stressors illumine the ethical import of place. Dialogue with some meaningful segment of the now voluminous moral and theological literature on the environment seems a necessary next step for Christian ethics aiming to approach ecologies of violence.

Two other books-Cynthia Moe-Lobeda's Resisting Structural Evil and Kevin O'Brien's The Violence of Climate Change-show how attention to religious environmental thought can help inform responses to climate violence. Both present compelling arguments that climate change should be understood as structural violence. Climate change is a keystone example of how economic and ecological exploitation interlock in complex, hidden, systemic patterns, argues Moe-Lobeda. ${ }^{71}$ "To see climate change as violence is to see it as the product of a destructive system that degrades human lives, other species, and the world upon which all living beings depend," writes $\mathrm{O}^{\prime}$ Brien. ${ }^{72}$

Writing to over-consuming, mostly North Atlantic Christians, Moe-Lobeda attempts to help readers see structural violence, recognize their complicity without lapsing into "moral oblivion" or overwhelmed paralysis, and develop theological resources for individual and collective resistance and reform. A central task is to develop the "ecological dimensions of love." Interpreting neighbor-love in the context of creation ties acts of justice and compassion toward non-human creatures to the fundamental vocation of Christian life. It binds human practices of minding "voices of earth" to the person of Jesus and the mystery of God-“"an incarnate God, a God embodied in life's extravagant complexity and variation."73 It also raises complicated questions about how moral norms forged for human individuals and societies apply to non-human species and biotic communities. Christian environmentalists too often ignore disjunctions between values of Christian morality and the principles of biology and especially Darwinian evolution, argues Lisa Sideris. Where this is the case, Christian ethics actually fails to attend to nature in its own integrity, and so pursues practical strategies unsettling to ecological systems. ${ }^{74}$ Moe-Lobeda acknowledges these complexities, but does not attempt to resolve them. "The challenge of retheorizing love as an ecological vocation" remains "a weighty and morally compelling challenge for religion of the early twenty-first century."75 Still, Moe-Lobeda

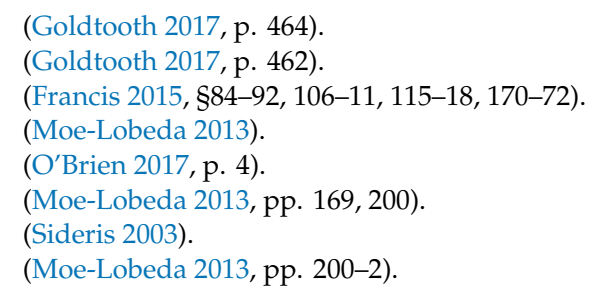


claims a theologically grounded and ethically articulated praxis of love can transform moral agency for meaningful confrontation with ecological violence.

Kevin O'Brien draws on religious environmental thought to help interpret the multi-dimensional and multi-scalar problems of climate change, and turns to five famous leaders of nonviolent social movements for insight and inspiration in the struggle for climate justice. O'Brien develops a brief argument (in conversation with environmental theologian Whitney Bauman) for treating climate change as a global problem requiring a "'planetary' morality, which embraces the wide diversity of life on planet Earth in each of its diverse local expressions." Because climate change is rooted in "anthropocentric habits of thought and behavior," ethics responsive to the violence of climate change must expand their moral visions to include other creatures and earth as a whole. ${ }^{76}$

While O'Brien includes ecological degradation as part of his account of the violence of climate change, he also argues that concern for non-human species and natural processes should be valued "pragmatically" in movements for climate justice. "Small steps in the right direction that have been democratically agreed upon are far more powerful than boldly radical statements that are widely dismissed," he writes. Eco-centric accounts of climate violence are politically marginal, and make the claims of climate justice significantly more demanding. Extoling the example of Jane Addams, O'Brien urges pragmatism, which in this case means narrowing the scope of moral attention to the human dimensions of ecological violence in order to allow wide cooperation toward meaningful progress on climate justice. ${ }^{77} \mathrm{O}^{\prime}$ Brien is willing to countenance what Goldtooth calls "violation of the sacred" in exchange for piecemeal, majoritarian improvements to climate politics. But the trade-off is made consciously, with a pragmatist's faith in the capacity of grassroots democracy to gradually cultivate the cultural and political shifts that may one day recognize the cries of the earth and the justice claims of indigenous communities. ${ }^{78}$

O'Brien's approach to the violence of climate change is also pragmatic in another sense. His book "begins not with an abstract claim but with a concrete challenge," i.e., the structural violence of climate change, understood at its many levels of moral, scientific and political complexity. By locating climate change in the realm of violence, $\mathrm{O}^{\prime}$ Brien emphasizes that the problem's ethical demands are not entirely unprecedented; moral communities have successfully resisted violence before. His approach seeks to cultivate capacities to engage climate violence by learning from social movements, with attention to how their ways of seeking justice and peace present both practical tools for climate action and theo-ethical insight about life in a warming world. ${ }^{79}$

\section{Doing Christian Ethics for Ecologies of Violence}

When O'Brien describes his approach to climate ethics as "pragmatic," he refers to the work of Willis Jenkins, who distinguishes between two broad strategies, two ways of doing religious ethics in response to social-environmental problems. In Jenkins' taxonomy, a pragmatic strategy "starts from concrete problems and works with the ideas and practices generated from reform projects attempting to address them." It holds that "the meaning of moral beliefs and practices lies in the patterns of action they support," and therefore looks to how moral communities adapt their traditions "to see and solve problems." The ethicist's task is to help moral communities use their traditions better. The other strategy is "cosmological." It attempts to meet moral challenges by telling "a new story or retrieving a forgotten moral vision in order to reorient humanity's moral consciousness." Where a pragmatic strategy trusts practices to transform moral vision, a cosmological strategy wagers that renewed worldviews can reshape moral practices. ${ }^{80}$ Where cosmology centers on core convictions and root

\footnotetext{
(O’Brien 2017, pp. 106, 111).

(O'Brien 2017, pp. 109-11).

Cf. O'Brien (2017) discussions of the climate threats to Kivalina, pp. 100-1, 113-14.

(O’Brien 2017).

80 (Jenkins 2013, pp. 1-15).
} 
metaphors, pragmatism looks to concrete cases of collective problem-solving. Taken together, the books discussed above indicate that efforts to help Christian ethics discern responsibilities for ecologies of violence will have to do both.

A major task for Christian ethics at the intersection of violence and the environment will be to re-envision social, political, and religious life within ecological systems-a challenge of moral cosmology. As Jennings and others point out, the segregation of corporate life from the wider communion of nature has circumscribed the Christian imagination in ways directly complicit with racialized violence, economic exploitation, and environmental desecration. It has also effectively obscured links between ecology, conflict, and structural violence, channeling Christian moral thought on politics and environment into separate pools, making it difficult to reckon with ecologies of violence whether in theory or in practice.

"After hundreds of years of thinking of war as primarily fought for political purposes," writes Douglas, "the return of resource wars, the weaponizing of environmental goods, the destabilizing effect of climate refugees, and the reshaping of mutually beneficial alliances (not to mention what will count as mutual benefit) ... will lead to a rethinking of the causes, types, exacerbating factors, and understandings of war in a warming world." ${ }^{\prime 81}$ This is all true, and yet war will still be fought primarily for political purposes. The defining mark of the environmental age is not the supersession of ecological forces over political life, but their mutual entanglement. Ecology is political; politics involves ecological relations, is shaped by landscape and nature's processes, and always has environmental ramifications.

Northcott, Douglas, and Moe-Lobeda all, in their own ways, attempt to reform the Christian imagination toward the capacity to see and accept responsibilities for violent political ecologies. Northcott restores God's presence to creation in order to reverse the catastrophic rupture of nature from culture. Douglas locates God's presence in the movement of Christian tradition through time in order to help communities tell their formative stories in ways that orient them to the distinct moral demands of an environmental age. Moe-Lobeda develops the meaning of Christian love to encompass the non-human world and to confront violence hidden in the convergences of economic structures and ecological relations.

If environmental conditions affect, integrate, and convey relationships of violence and domination, the flip side is that peace and flourishing are bound up with ecology. Another important site of attention for Christian ethics could be to flesh out the theological significance of God's peace for the moral challenges of political ecology. A number of Christian leaders have already indicated the importance of expounding the ecological dimensions of Christian conceptions of peace. "In our day," stated Pope John Paul II in his message for the 1990 celebration of the World Day of Peace, "there is a growing awareness that world peace is threatened not only by the arms race, regional conflict and continued injustice among peoples and nations, but also by a lack of due respect for nature, by the plundering of natural resources and by a progressive decline in the quality of life." 82 "Protecting the natural environment in order to build a world of peace is ... a duty incumbent upon each and all" argued Pope Benedict XVI at the same celebration twenty years later. ${ }^{83}$ Pope Francis built on such themes in Laudato $5 i{ }^{84}$ While the Popes argue that environmental protections are crucial to peace, the World Council of Churches (WCC) insists that peace is generative of ecological integrity: "The earth calls for and is in desperate need of a vision of peace that will enable it to restore itself in accord with its own intrinsic dynamism." ${ }^{\prime 85}$ For the popes, the WCC, and a number of other Christian environmental thinkers, environmental issues

81 (Douglas 2019, p. 102).

82 (John Paul 1990, §1). Emphasis in the original.

83 (Benedict 2010, §14). For critical commentary, and a "creatiocentric" extension of Catholic Social Teaching's ways of linking environmental issues to peace and nonviolence, see (Thompson 2012).

84 (Francis 2015). See also (Winright 2018).

85 (World Council of Churches 2008). 
are peace issues not primarily because ecological problems spark violence. Peace is a fundamental category of environmental ethics, they suggest, because biblical or theological conceptions of peace are holistic and expansive. The Hebrew word for peace, shalom, involves not only inter-human harmony within conditions of social justice, but further denotes God's ultimate intentions for the flourishing of all creation in loving fellowship with the Creator. ${ }^{86}$ God's will for peace is coextensive with God's designs for creation, such that the earth's travail frustrates God's longing to draw the world into communion with Godself. According to this framework, ecological degradation sabotages shalom, and warped visions of peace devastate the environment.

Cosmological strategies become necessary, suggests Jenkins, when "a culture's moral inheritances can no longer be trusted." ${ }^{\prime 7}$ Faced with a set of unexamined ethical challenges-ecologies of violence that are not only ignored but also entrenched and concealed within North Atlantic Christian traditions-it may be useful to let constructive theology mend the moral imagination. "Ethics may need the religious capacity to reconsider the basic story by which [the] culture lives." ${ }^{\prime 88}$ On the other hand, Christian ethics has a tendency to overestimate the power of theological beliefs to transform cultures, and cosmological strategies direct attention to grand theories and big ideas, funneling energy away from "concrete problems, scientific learning, pluralist negotiations, and the dynamics of cultural change." ${ }^{\prime 99}$ Pragmatic strategies attempt to correct these liabilities.

If the cosmological challenge is to re-envision human life within ecological systems, the pragmatic challenge is to equip ecological communities to practically engage problems linking violence and environment. A key step will be to attend carefully to the details of various types and instances of violent ecology. The four types outlined above are all quite different, and all take on distinct aspects when the scope of attention changes from general types to specific cases. Land conflict looks different in America's eastern coal country than it does in western ranchlands; both take on new valences where native peoples claim rights to ancestral lands; there are other kinds of differences between North American conflicts and those in the Middle East or in South Asia. Each form of ecological violence is embroiled in important debates in the natural and social sciences, and each has provoked morally significant political, legal, and philosophical discussions. Just as reckoning with the challenges of modern economy or contemporary politics requires scrutinizing over how each of these systems actually functions, ${ }^{90}$ understanding what is at stake for Christian ethics in ecologies of violence will require getting acquainted with today's political ecologies.

Another step will be to consider how Christian communities and other movements around the world are already engaging ecologies of violence in practical ways. Collaboration with and critical reflection on real efforts to confront contextual problems is at the heart of Jenkins' pragmatic strategy, which runs on "the moral creativity in religious reform projects." 91 This may be particularly important when attempting to come to grips with problems like environmental conflict, the environmental impacts of war, land conflict, or the structural violence of climate change, because the tradition has virtually no history of scholarly reflection on these issues, and because its conceptual tools for addressing them are underdeveloped.

Allowing problems and the practical projects that engage them to tutor Christian ethics will require case-based analyses and place-based forms of moral reflection. Taking responsibility for ecologies of violence involves re-envisioning Christian ethics as a practice of orienting Christian life within the diverse relations constitutive of a place. Reflecting on cases of violence grounded in environmental

86 Cf. (Wirzba 2003).

87 (Jenkins 2013, p. 159).

88 (Jenkins 2013, p. 166). This is roughly the argument and the approach taken by ecofeminist theologian Sallie McFague across a number of books responsive to climate change and other environmental challenges. Among others, see (McFague 1993, 2001, 2008).

89 (Jenkins 2013, pp. 4-5).

90 e.g., (Tanner 2019; Bretherton 2010).

91 (Jenkins 2013, p. 5). 
conditions or conveyed in ecological systems rivets attention to the geography of moral life, so the field of Christian ethics must find ways to geo-locate its work, perhaps by finding its source materials within embodied Christian communities living their body politics in confrontation with violent ecologies.

Both cosmological and pragmatic strategies for reckoning with ecologies of violence will need to employ a third approach: Christian ethics must develop a dialogical method. Where contemporary problems transgress traditional intellectual and agential boundaries, ethics needs ways to orient moral life in processes of integration, critique, collaboration and exchange. Doing Christian ethics for ecologies of violence involves several kinds of dialogue, including interdisciplinary investigations needed to grasp the issues, inter-religious and cross-cultural dialogues necessary to understand and address particular cases, theological exchanges between schools of environmental and political reflection, and participatory learning across movements of practical response. Christian engagements with ecologies of violence will inevitably take on the diverse and distinct theological and methodological habits of the Christian spectrum, but dialogue should characterize the full range.

Traci West argues that dialogue is central to doing Christian ethics because the field's central task is "to make responsible contributions to the shared values of our pluralistic world." Collaborating toward moral engagement with intersectional problems within conditions of pluralism entails putting the tradition's theo-ethical inheritances in conversation with the moral wisdom embedded in communities of practice. In Disruptive Christian Ethics, West develops a method of ethics driven by "conversations between text and social context," allowing "the theories and practices, texts and contexts that are examined [to] critique each other." Doing Christian ethics for ecologies of violence may press the field in the directions blazed by scholars like Traci West-toward ethics as dialogical negotiation over intersectional problems with the goal of "building more ethical communal relations." 92

One key area for dialogue will be between environmental ethics and the ethics of war and peace, including conversations between each field's moral and theological frameworks and between the communities of practice that carry them. The reasons for such dialogues are clear. Having developed in mutual isolation, and now facing problems that outstrip their respective ethical competencies, in part by crossing into the other's domain, each stands to learn from the other what a Christian response to ecologies of violence might entail. Paradigms of war/peace ethics each have practical repertories for criticizing violence, for limiting, preventing, and even healing it. They can stimulate debate about the acceptability, scope, ends and means of violence and warfare. Paradigms of environmental ethics have capacities for criticizing environmental degradation, and have shown themselves especially creative in working with inherited moral traditions to develop new forms of ethical responsibility. They also have experience articulating forms of responsibility that cross social, political, ecological, and bio-physical spheres of live.

The grounds for such dialogue are also transparent. Both subfields frame their moral inquiries under the general task of orienting Christian life in response to God. Although specialized ethical arenas, they share common, theologically articulated norms (e.g., love and justice), as well as key inheritances (e.g., scripture and other authoritative texts, theological motifs, and exemplars) that have always shaped Christian ethics, so that the sources and structures of human obligation and Christian responsibility within both subfields ultimately cluster around common themes or debates. Yet there are important differences between environmental ethics and the ethics of violence. While the two must now be interwoven, they cannot be collapsed into each other without problems. In practice, the two reason differently about what is at stake in ecologies of violence; they work with incommensurable criteria to evaluate adequate responses, and they supply divergent resources to get there. Still they must develop practices of critical collaboration if they are to contribute to practical reasoning about the connections between violence and natural environment.

92 (West 2006, pp. xv-xxi). 
The era of thinking ethically about justice and peace in abstraction from ecological systems and environmental conditions is passed. What this means for Christian ethics depends in part on how Christians come to interpret and perform the moral and theological significance of humanity's relations with non-human creation, and so on how ethics discerns the significance of place for moral reflection and Christian life. It also hinges on how Christians understand, evaluate, and inhabit their ecological connections with both neighbors and enemies, and so on how they adapt the tradition's theories and practices of violence, nonviolence, warfare and peacemaking. It will rely on developing dialogue as fundamental to the discipline, and allowing conversations across texts and contexts to stimulate moral imagination. In these exercises, Christians will find new ways to image God's peace amidst ecologies of violence.

Funding: This research received no external funding.

Conflicts of Interest: The authors declare no conflict of interest.

\section{References}

Agarwal, Anil, and Sunita Narain. 1991. Global Warming in an Unequal World: A Case of Environmental Colonialism. New Delhi: Centre for Science and Environment.

Alvarez, Alex. 2017. Unstable Ground: Climate Change, Conflict, and Genocide. Lanham: Rowman \& Littlefield Publishers.

Austin, Jay E., and Carl E. Bruch, eds. 2000. The Environmental Consequences of War: Legal, Economic, and Scientific Perspectives. New York: Cambridge University Press.

Baker-Fletcher, Karen. 1998. Sisters of Dust, Sisters of Spirit: Womanist Wordings on God and Creation. Minneapolis: Fortress Press.

Barnett, Jon, and Stephen Dovers. 2001. Environmental Security, Sustainability, and Policy. Pacifica Review 13: 157-69. [CrossRef]

Benedict, Pope, XVI. 2010. If You Want to Cultivate Peace, Protect Creation. Message for the Celebration of the World Day of Peace. January 1. Available online: http://w2.vatican.va/content/benedict-xvi/en/messages/ peace/documents/hf_ben-xvi_mes_20091208_xliii-world-day-peace.html (accessed on 20 July 2019).

Brauch, Hans Günter. 2009. Securitizing Global Environmental Change. In Facing Environmental Change: Environmental, Human, Energy, Food, Health and Water Security Concepts. Edited by John Grin, Brauch Hans Gunter, Heinz Krummenacher, Czeslaw Mesjasz and Patricia Kameri-Mbote. Berlin: Springer, pp. 65-102.

Bretherton, Luke. 2010. Christianity and Contemporary Politics: The Conditions and Possibilities of Faithful Witness. Malden: Wiley-Blackwell.

Broome, John. 2012. Climate Matters: Ethics in a Warming World. New York: W. W. Norton \& Company.

Buhaug, Halvard, Jonas Nordkvelle, Thomas Bernauer, Tobias Böhmelt, Michael Brzoska, Joshua W. Busby, and Antonio Ciccone. 2014. One Effect to Rule Them All? A Comment on Climate and Conflict. Climatic Change 127: 391-97. [CrossRef]

Bullard, Robert. 1990. Dumping in Dixie: Race, Class and Environmental Quality. Boulder: Westview Press.

Bullard, Robert, Paul Mohai, Robin Saha, and Beverly Wright. 2007. Toxic Wastes and Race at Twenty, 1987-2007. Cleveland: United Church of Christ Justice and Witness Ministries, United Church of Christ.

Burke, Marshall, Solomon M. Hsiang, and Edward Miguel. 2015. Climate and Conflict. Annual Review of Economics 7: 577-617. [CrossRef]

Buzan, Barry, Ole Wæver, and Jaap de Wilde. 1998. Security: A New Framework for Analysis. Boulder: Lynne Rienner.

Conca, Ken, and Geoffrey D. Dabelko. 2002. Environmental Peacemaking. Washington, DC: Woodrow Wilson Center Presss.

Cone, James. 2001. Whose Earth Is It Anyway? In Earth Habitat: Eco-Injustice and the Church's Response. Edited by Dieter Hessel and Larry Rasmussen. Minneapolis: Fortress Press, pp. 23-32.

Detraz, Nicole. 2015. Environmental Security and Gender. New York: Routledge.

Deudney, Daniel. 1990. The Case against Linking Environmental Degradation and National Security. Millenium: Journal of International Studies 19: 461-76. [CrossRef] 
Deudney, Daniel H. 1999. Environmental Security: A Critique. In Contested Grounds: Security and Conflict in the New Environmental Politics. Edited by Daniel Deudney and Richard A. Matthew. Albany: SUNY Press, pp. 187-219.

Diederich, Michael D. 1992. 'Law of War' and Ecology: A Proposal for a Workable Approach to Protecting the Environment Through the Law of War. Military Law Review 136: 137-60.

Diehl, Paul F., and Nils Petter Gleditsch, eds. 2001. Environmental Conflict. Boulder: Westview Press.

Douglas, Mark. 2019. Christian Pacifism for an Environmental Age. New York: Cambridge University Press.

Doyle, Timothy, and Sanjay Chaturvedi. 2012. Climate Refugees and Security: Conceptualizations, Categories, and Contestations. In The Oxford Handbook of Climate Change and Society. Edited by John S. Dryzek, Richard B. Norgaard and David Schlosberg. New York: Oxford University Press. [CrossRef]

Duffy, Rosaleen. 2014. Waging a War to Save Biodiversity: The Rise of Militarized Conservation. International Affairs 90: 819-34. [CrossRef]

Eckersley, Robyn. 2007. Ecological Intervention: Prospects and Limits. Ethics and International Affairs 21: $293-316$. [CrossRef]

Elshtain, Jean Bethke. 1987. Women and War. Chicago: University of Chicago Press.

Farrell, Justin. 2015. The Battle for Yellowstone: Morality and the Sacred Roots of Environmental Conflict. Princeton: Princeton University Press.

Francis, Pope. 2015. Laudato Si: On Care for Our Common Home. In The Holy See. Vatican City: Libreria Editrice Vaticana.

Galtung, Johann. 1969. Violence, Peace, and Peace Research. Journal of Peace Research 6: 167-91. [CrossRef]

Glave, Dianne. 2006. Black Environmental Liberation Theology. In To Love the Wind and the Rain: African Americans and Environmental History. Edited by Dianne Glave and Mark Stoll. Pittsburgh: University of Pittsburgh Press, pp. 189-99.

Goldtooth, Tom B. K. 2017. Respect for Mother Earth: Original Instructions and Indigenous Traditional Knowledge. In The Wiley Blackwell Companion to Religion and Ecology. Edited by John Hart. Hoboken: Wiley.

Graeger, Nina. 1996. Environmental Security? Journal of Peace Research 33: 109-16. [CrossRef]

Grunawalt, Richard J., John E. King, and Ronald S. McClain, eds. 1996. Protection of the Environment During Armed Conflict. In International Law Studies. Newport: Naval War College.

Harris, Melanie L. 2017. Ecowomanism: African American Women and Earth-Honoring Faiths. Maryknoll: Orbis Books. Homer-Dixon, Thomas. 1999. Environment, Scarcity, and Violence. Princeton: Princeton University Press.

Hsiang, Solomon, Kyle Meng, and Mark Cane. 2011. Civil Conflicts are Associated with the Global Climate. Nature 476: 438-41. [CrossRef] [PubMed]

Hupy, Joseph P. 2008. The Environmental Footprint of War. Environment E History 14: 405-21.

Jenkins, Willis. 2013. The Future of Ethics. Washington, DC: Georgetown University Press.

Jenkins, Willis. 2017. Is Climate Change Structural Violence. Paper presented at the Annual Meeting of the Society of Christian Ethics, New Orleans, LA, USA, January 5-8.

Jenkins, Willis. 2018. White Settler Christianity and the Silence of Earth in Political Theology. Political Theology Network, Symposium on Political Theology and Ecology. Available online: https://politicaltheology.com/ naturalized-white-settler-christianity-and-the-silence-of-earth-in-political-theology/ (accessed on 2 August 2019).

Jenkins, Willis, Evan Berry, and Luke Beck Kreider. 2018. Religion and Climate Change. Annual Review of Environment and Resources 43: 85-108. [CrossRef]

Jennings, Willie J. 2010. The Christian Imagination: Theology and the Origins of Race. New Haven: Yale University Press.

Jensen, David, and Steve Lonergan, eds. 2012. Assessing and Restoring Natural Resources in Post-Conflict Peacebuilding. New York: Routledge.

John Paul, Pope, II. 1990. Peace with God the Creator, Peace with All of Creation. Message for the Celebration of the World Day of Peace. January 1. Available online: http://w2.vatican.va/content/john-paul-ii/en/messages/ peace/documents/hf_jp-ii_mes_19891208_xxiii-world-day-for-peace.html (accessed on 20 July 2019).

Johnston, Laurie. 2015. Just War and Environmental Destruction. In Can War Be Just in the $21^{\text {st }}$ Century? Ethicists Engage the Tradition. Edited by Tobias Winright and Laurie Johnston. Maryknoll: Orbis Books, pp. 96-111.

King, Martin Luther, Jr. 1991. A Time to Break Silence. In A Testament of Hope. Edited by James M. Washington. New York: HarperCollins, pp. 231-44. 
Klare, Michael T. 2001. Resource Wars: The New Landscape of Global Conflict. New York: Henry Holt and Company. Martinez-Alier, Joan. 2002. The Environmentalism of the Poor: A Study of Ecological Conflicts and Valuation. Northampton: Edward Elgar.

Martin-Schramm, James. 2010. Climate Justice: Ethics, Energy, and Public Policy. Minneapolis: Fortress Press.

McFague, Sallie. 1993. The Body of God: An Ecological Theology. Minneapolis: Fortress Press.

McFague, Sallie. 2001. Life Abundant: Rethinking Theology and Economy for a Planet in Peril. Minneapolis: Fortress Press.

McFague, Sallie. 2008. A New Climate for Theology: God, the World, and Global Warming. Minneapolis: Fortress Press. Moe-Lobeda, Cynthia. 2013. Resisting Structural Evil: Love as Ecological-Economic Vocation. Minneapolis: Fortress. Nixon, Rob. 2011. Slow Violence and the Environmentalism of the Poor. Cambridge: Harvard University Press.

Northcott, Michael S. 2007. A Moral Climate: The Ethics of Global Warming. Maryknoll: Orbis Books.

Northcott, Michael S. 2013. A Political Theology of Climate Change. Grand Rapids: Eerdmans.

Northcott, Michael S. 2017. Climate Change and Christian Ethics. In The Wiley Blackwell Companion to Religion and Ecology. Edited by John Hart. Hoboken: John Wiley \& Sons, pp. 286-300.

O'Brien, Kevin J. 2017. The Violence of Climate Change: Lessons of Resistance from Nonviolent Activists. Washington, DC: Georgetown University Press.

Parenti, Christian. 2011. Tropic of Chaos: Climate Change and the New Geography of Violence. New York: Nation Books.

Parsons, Rymn J. 2010. Climate Change: The Hottest Issue in Security Studies? Risk, Hazards E Crisis in Public Policy 1: 87-116.

Purdy, Jedediah. 2015. After Nature: A Politics for the Anthropocene. Cambridge: Harvard University Press.

Rayfuse, Rosemary, ed. 2014. War and the Environment: New Approaches to Protecting the Environment in Relation to Armed Conflict. Leiden: Brill Nijhoff.

Reichberg, Gregory, and Henrik Syse. 2000. Protecting the Natural Environment in Wartime: Ethical Considerations from the Just War Tradition. Journal of Peace Research 37: 449-68. [CrossRef]

Roberts, J. Timmons, and Bradley Parks. 2006. A Climate of Injustice: Global Inequality, North-South Politics, and Climate Policy. Cambridge: The MIT Press.

Roberts, J. Timmons, and Bradley C. Parks. 2009. Ecologically Unequal Exchange, Ecological Debt, and Climate Justice: The History and Implications of Three Related Ideas for a New Social Movement. International Journal of Comparative Sociology 50: 385-409. [CrossRef]

Ruether, Rosemary Radford. 1975. New Woman, New Earth: Sexist Ideologies and Human Liberation. New York: Seabury Press.

Schmitt, Michael. 1997. Green War: An Assessment of the Environmental Law of International Conflict. Yale Journal of International Law 22: 1-109.

Shadle, Matthew. 2011. No Peace on Earth: War and the Environment. In Green Discipleship: Catholic Theological Ethics and the Environment. Edited by Tobias Winright. Winona: Anselm Academic, pp. 407-425.

Shue, Henry. 2016. Climate Justice: Vulnerability and Protection. New York: Oxford University Press.

Sideris, Lisa. 2003. Environmental Ethic, Ecological Theology and Natural Selection. New York: Columbia University Press.

Stockholm International Peace Research Institute. 1975. Delayed Toxic Effects of Chemical Warfare Agents. Stockholm: Amkqvist \& Wiksell International.

Stockholm International Peace Research Institute. 1976. Ecological Consequences of the Second Indochina War. Edited by Arthur H. Westing. Stockholm: Almqvist \& Wiksell.

Stone, Christopher D. 2000. The Environment in Wartime: An Overview. In The Environmental Consequences of War: Legal, Economic, and Scientific Perspectives. Edited by Jay Austin and Carl E. Bruch. New York: Cambridge University Press, pp. 16-35.

Tanner, Kathryn. 2019. Christianity and the New Spirit of Capitalism. New Haven: Yale University Press.

Thistlethwaite, Susan Brooks. 2015. Women's Bodies as Battlefield: Christian Theology and the Global War on Women. New York: Palgrave Macmillan.

Thompson, J. Milburn. 2012. Treating Nature Nonviolently: Developing Catholic Social Teaching on the Environment through Nonviolence. In Violence, Transformation, and the Sacred. Edited by Margaret R. Pfeil and Tobias L. Winright. Maryknoll: Orbis Books, pp. 225-38.

Tinker, George. E. 1997. An American Indian Theological Response to Ecojustice. Ecotheology 3: 85-109. [CrossRef] Tinker, George E. 2008. American Indian Liberation: A Theology of Sovereignty. Maryknoll: Orbis Books. 
United Nations Environment Programme. 2009. From Conflict to Peacebuilding: The Role of Natural Resources and the Environment. Nairobi: United Nations Environment Programme.

United Nations Environmental Program. 2009. Protecting the Environment During Armed Conflict: An Inventory and Analysis of International Law. Nairobi: United Nations Environmental Program.

United States Department of Defense. 2015. National Security Implications of Climate-Related Risks and a Changing Climate; Washington, DC: US Department of Defense.

Walzer, Michael. 2004. Arguing About War. New Haven: Yale University Press.

Warren, Karen, ed. 1997. Eco-Feminism: Women, Culture, Nature. Bloomington: Indiana University Press.

West, Traci. 2006. Disruptive Christian Ethics: When Racism and Women's Lives Matter. Lexington: Westminster John Knox.

Westing, Arthur H. 1990. Environmental Hazards of War: Releasing Dangerous Forces in an Industrialized World. London: Sage Publications.

Williams, Delores. 1993. Sin, Nature and Black Women's Bodies. In Ecofeminism and the Sacred. Edited by Carol J. Adams. New York: Continuum, pp. 24-29.

Winright, Tobias. 2018. Peace on Earth, Peace with Earth: Laudato Si' and Integral Peacebuilding. In All Creation Is Connected: Voices in Response to Pope Francis's Encyclical on Ecology. Edited by Daniel R. DiLeo. Winona: Anselm Academic.

Wirzba, Norman. 2003. The Paradise of God: Renewing Religion in an Ecological Age. New York: Oxford University Press.

Woods, Mark. 2007. The Nature of War and Peace: Just War Thinking, Environmental Ethics, and Environmental Justice. In Rethinking the Just War Tradition. Edited by Michael W. Brough, John W. Lango and Harry van der Linden. Ithaca: SUNY Press, pp. 17-34.

World Council of Churches. 2008. Peace on Earth and Peace with the Earth. Paper presented at the Memorandum from WCC Symposium Peace on Earth is Peace with the Earth: Peace of Creation, Geneva, Switzerland, September 14-18.

Zeitoun, Mark. 2013. Global Environmental Justice and International Transboundary Waters: An Initial Exploration. The Geographical Journal 179: 141-49. [CrossRef]

(C) 2019 by the author. Licensee MDPI, Basel, Switzerland. This article is an open access article distributed under the terms and conditions of the Creative Commons Attribution (CC BY) license (http://creativecommons.org/licenses/by/4.0/). 